\title{
Dementia and cognitive impairment in adults as sequels of HSV-1-related encephalitis \\ a review
}

\author{
Emille Magalhães Neves Campos ${ }^{1}{ }^{\circledR}$, Laís Damasceno Rodrigues ${ }^{2}{ }^{\odot}$, \\ Leandro Freitas Oliveira ${ }^{\odot}$, Júlio César Claudino dos Santos ${ }^{2,3}{ }^{\circ}$
}

\begin{abstract}
Considering the variety of mechanisms of Herpes simplex virus (HSV-1) contamination and its broad invasive potential of the nervous system, a life-long latent infection is established. Infected adult individuals may be susceptible to viral reactivation when under the influence of multiple stressors, especially regarding immunocompromised patients. This guides a series of neuroinflammatory events on the cerebral cortex, culminating, rarely, in encephalitis and cytotoxic / vasogenic brain edema. A sum of studies of such processes provides an explanation, even though not yet completely clarified, on how the clinical evolution to cognitive impairment and dementia might be enabled. In addition, it is of extreme importance to recognize the current dementia and cognitive deficit worldwide panorama. The aim of this literature review is to elucidate the available data upon the pathophysiology of HSV-1 infection as well as to describe the clinical panorama of the referred afflictions.
\end{abstract}

Keywords: herpesvirus 1, human, central nervous system viral diseases, encephalitis, herpes simplex, cognitive dysfunction, dementia.

\section{DEMÊNCIA E DÉFICIT COGNITIVO EM ADULTOS COMO SEQUELAS DE ENCEFALITE RELACIONADA AO HSV-1:UMA REVISÃO}

RESUMO. Considerando a variedade de mecanismos de contaminação pelo vírus Herpes simplex (HSV-1) e seu amplo potencial invasivo do sistema nervoso, uma infecção latente por toda a vida é estabelecida. Indivíduos adultos infectados podem ser suscetíveis à reativação viral quando estão sob a influência de múltiplos estressores, principalmente em pacientes imunocomprometidos. Esse fator orienta uma série de eventos neuroinflamatórios no córtex cerebral, culminando, raramente, em encefalite e edema cerebral citotóxico/vasogênico. Um somatório de estudos desses processos fornece uma explanação, embora ainda não totalmente esclarecida, de como a evolução clínica para déficit cognitivo e demência pode ser possibilitada. Além disso, é de extrema importância reconhecer o panorama mundial atual da demência e do déficit cognitivo. 0 objetivo da presente revisão de literatura é elucidar os dados disponíveis sobre a fisiopatologia da infecção pelo HSV-1, assim como descrever o panorama clínico das referidas afecções.

Palavras-chave: herpesvírus humano 1, viroses do sistema nervoso central, encefalite por herpes simples, disfunção cognitiva, demência.

\section{INTRODUCTION}

The herpes simplex virus type 1 (HSV-1)

1 is a double-stranded DNA virus and belongs to the Alphaherpesvirinae subfamily, ${ }^{1}$ whose genome encodes more than 80 different open reading frames. Characterized by a short intracellular replication cycle, with rapid destruction of the host cell, HSV-1 can alternate between an infectious lytic phase, producer of infectious virions, and a latent state, which enables a long-term persistence of infection, dissemination and escape from the immune system surveillance. ${ }^{2}$

Its broad neurotropic potential dictates a wide spectrum of clinical disorders, ranging from simpler mucocutaneous manifestations,

\footnotetext{
This study was conducted at the Neurology and Neurosurgery Service, Universidade Federal de São Paulo, São Paulo, SP, Brazil.

${ }^{1}$ Faculty of Medicine, Federal University of Roraima, Boa Vista, RR, Brazil. ${ }^{2}$ Neuroscience Laboratory, Department of Neurology and Neurosurgery, Federal University of São Paulo, São Paulo, SP, Brazil. ${ }^{3}$ Faculty of Medicine, Christus University Center, Fortaleza, CE, Brazil.
}

Júlio César Claudino dos Santos. Departamento de Neurologia e Neurocirurgia. Universidade Federal de São Paulo. Rua Sena Madureira, 1500 - Vila Clementino 04021-001 São Paulo SP - Brazil. E-mail: cesar.claudino@unifesp.br

Disclosure: The authors report no conflicts of interest.

Funding: none.

Received on October 24, 2020. Accepted in final form on February 01, 2021.

\section{(c) BY}


such as oral and facial injuries, to serious infections of the central nervous system (CNS). Among these, HSVs account for 50 to $75 \%$ of viral encephalitis, which consist of brain parenchyma inflammation associated with clinical evidence of neurologic dysfunctions, such as reduced consciousness, behavioral alterations, and impaired cognitive function. ${ }^{3}$ The herpetic encephalitis (HSE) is responsible for a high mortality rate between patients who do not receive antiherpetic treatment and for over $70 \%$ of neurological sequelae in surviving patients. ${ }^{3}$

Given the HSV-1 wide invasive potential of the CNS, it is able not only to agglomerate in the dorsal root nerve ganglia (DRG), but also to migrate to the cerebral cortex itself, including the orbitofrontal, insular, and mesial temporal lobe regions, specially affecting the hippocampus, ${ }^{4}$ whose vulnerability to Alzheimer disease is substantial, as demonstrated in pioneer and recent studies. ${ }^{5-7}$ Furthermore, evidence carried out with animal models prove that the area analogous to the human limbic cortex is commonly affected by encephalitis. A contralateral temporal lobe spread may as well occur via the anterior commissure. ${ }^{8}$

Most cases of encephalitis in adults are related to viral infection by HSV-1. ${ }^{9}$ This scenario enables the clinical evolution to neuroinflammatory and glial damage processes,${ }^{10}$ mostly threatening immunocompromised or immunosuppressed patients, whose possible unfavorable prognosis are cognitive impairment and dementia. ${ }^{11,12}$ Such entities, nevertheless, are also likely to occur in infected individuals without previous encephalitis. ${ }^{13-15}$ These disorders are widely correlated in several studies on the pathophysiology of Alzheimer disease in aged individuals with comorbidities, but are scarce among healthy adult individuals, in which the pathogenesis is still uncertain. A summary of the main works regarding HSV-1 infection and Alzheimer disease and neurodegeneration can be found in Figure 1. The aim of this literature review was to elucidate the pathophysiology of the neuroinflammation due to HSV-1 encephalitis and its clinical evolution to cognitive impairment and dementia in adults, as well as to describe the respective clinical panorama.

\section{METHODS}

A narrative literature review was conducted in the Medline and Science Direct Databases, from 2010 to 2020, on dementia, cognitive impairment, and the HSV-1

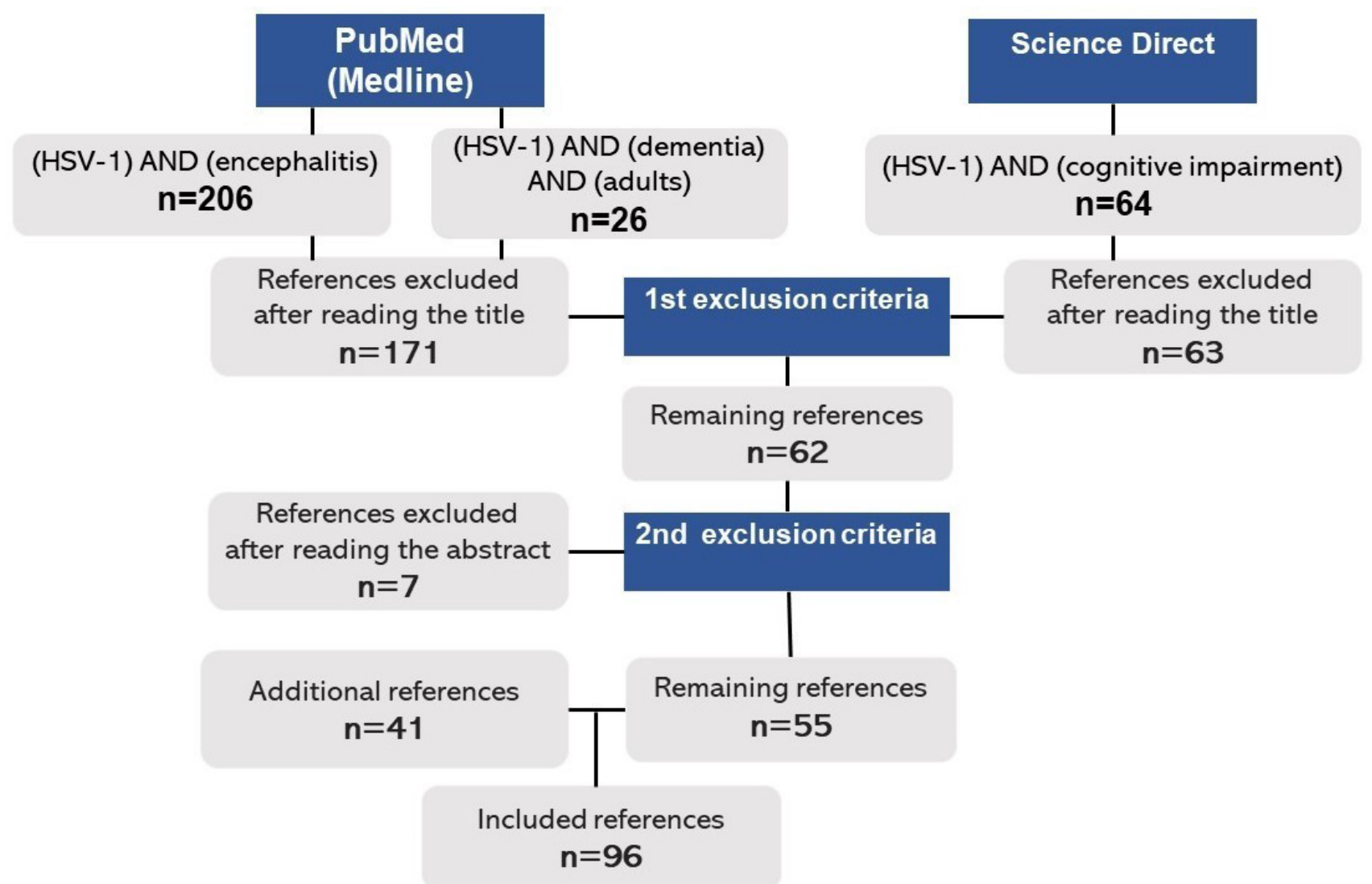

AD: Alzheimer disease; CNS: central nervous system; APOE4: apolipoprotein E4; APP: amyloid precursor protein; aMCl: amnestic mild cognitive impairment; A 3 : amyloid-beta plaques.

Figure 1. Articles addressing to HSV-1 infection and Alzheimer disease/neurodegeneration. 
encephalitis/infection. In the Medline Database, 206 articles were found by the Mesh descriptor "(HSV-1) AND (encephalitis)", of which 48 were selected, after the first set of criteria - exclusion of titles not addressing to the topic 'HSV-related encephalitis', articles not included in the search period 2010-2020, as well as non-English articles. Following the same exclusion criteria, 13 of 26 articles were selected by the descriptor "(HSV-1) AND (dementia) AND (adults)" from the Science Direct Database. When searching the descriptor "(HSV-1) AND (cognitive impairment)" in the same database, a total of 64 articles from the year 2020 were summarized, of which 1 was selected. The second set of criteria exclusion of the abstracts not addressed to HSV as the cause for encephalitis in adults - was applied, by which 7 articles were excluded. However, in such criteria, experiments on animal models were included due to the analogous relation between the cortical areas affected and those in the human brain. Moreover, although not being the target population, some studies with older individuals (age >60) were also included when addressing to the HSV reactivation frequency follow-up and its potential risk for Alzheimer disease. Other articles that did not contemplate these conditions were excluded. Furthermore, 41 articles from the Medline Database were manually screened and added according to their relevance in the qualitative evidence synthesis. Of the total, 96 original articles in English (including book chapters, guidelines, and case reports) remained.

\section{MECHANISMS OF THE HSV-1 INFECTION}

Considering the mechanisms by which HSV-1 reaches the CNS for the development of HSE, some pathways are elucidated, either by primary or secondary infection. ${ }^{16}$ Among these routes of contamination, there is the olfactory/trigeminal tract, the hematogenous via, and the peripheral ganglia reactivation.

The first mechanism includes the oropharyngeal via toward the olfactory epithelium neurons and posteriorly retrograde axonal transport to the olfactory bulb in the brain. This type of infection usually occurs first in the axonal termini of peripheral neurons of the trigeminal ganglion (TG), which innervate the orofacial or corneal layer. ${ }^{17}$ Given the fact that trigeminal neurons are pseudounipolar, the ascendent pathway of one branch projects into the thalamus and sensory cortex, whereas the other branch reaches the trigeminal nucleus in the brainstem. This factor enables new viral particles to migrate to the CNS through anterograde route. Hence, trigeminal neurons have been considered as the gateway to HSV-1 in the CNS. ${ }^{18}$
Eventually, the hematogenous vertical transmission route is possible after previous infection of the mother and subsequent access of HSV-1 to the placenta through the bloodstream. In addition, the contamination of the newborn includes the peripartum and postnatal periods, ${ }^{19}$ as reported in the study carried out by Avila and coworkers in southern Brazil, in which 480 placenta and umbilical cord biopsies of postpartum women were analyzed. The prevalence of HSV-1 infection in placental DNA was $37.5 \%$ compared to $27.5 \%$ in the umbilical cord. ${ }^{20}$ After entering the fetal organism, the virus migrates to the brain, establishing itself in the hippocampus. The infection also extends to neural stem cells in the subventricular zone of the lateral ventricle and to the hippocampal subgranular zone, affecting cell maturation, differentiation, and proliferation. $^{21}$

The third mechanism of viral dissemination is represented by peripheral ganglia reactivation with subsequent axonal migration to the CNS after an episode of recurrent orofacial infection by HSV $-1 .{ }^{22}$ However, latent in situ reactivation of the virus in the CNS tissue is eventually found, when under the influence of stressors, such as fever, sunlight, immunosuppression, emotional stress, exposure to ultraviolet rays, hormonal changes, dental surgery, and head trauma. ${ }^{23-26}$

Latent HSV-1 infection is guided by many factors of the human nervous system, thereby the same viral etiology is responsible for primary infections located in the same site of cutaneous distribution in immunocompetent individuals. ${ }^{27}$ Viral reactivation is likely to occur at any time in the patient's life, unlike primary infection, which usually occurs between two to three decades of life. ${ }^{27}$ In a prospective study on risk factors for HSV-1 infection/reactivation of a British populational base, conducted by Forbes and collaborators, such incidence was correlated with the increasing age and lower educational level and socioeconomic status of the population. The female seropositive portion $(64.2 \%)$, between the age group of 50-59, had higher HSV-1 infection and the highest reactivation rates, whose values were 59.2 and $20.4 \%$, respectively. ${ }^{28}$ This result is in accordance with the data from previous studies. ${ }^{29,30}$

Regardless of whether individual show symptoms after infection with HSV, the life-long infection with the virus implicates metabolic alterations in neuronal cells, increasing pathological mechanisms in the body and brain of some infected hosts. ${ }^{31,32}$ The physiological effects possibly culminate, among those with a worse prognosis, in herpetic encephalitis and consequent cognitive dysfunction. . $^{12,17,27,33}$ 


\section{LYTIC AND LATENT HSV-1 INFECTION: GENE MODULATION}

The fusion of HSV-1 with the neuronal membrane of sensory neurons at the axonal termini enables viral spread from its primary site of infection. Its nucleocapsid then is retrogradely transported to a ganglion (usually the trigeminal ganglion) and reaches the nucleus in the cell body, where it releases its DNA in an episomal form. During lytic infection, several genes are expressed in a cascade pattern, in which the viral transcriptional protein (VP16) is responsible for the immediate-early (IE) gene expression. IE gene products are expressed after 2-4 hours of the primary infection, i.e., infected cell protein 0 (ICP0), ICP4, ICP22, ICP27, and ICP47, that consequently activate the expression of early (E) and late (L) genes and stimulate viral DNA replication. Therefore, during lytic infection, the VP16 viral protein acts not only in the general chromatin reduction, but also in the alteration of euchromatin from the histones associated with HSV lytic genes. ${ }^{34}$ ICP-0 and US3 viral gene products also execute important functions by inhibiting the viral genome silencing and conducting viral expression in the host. ${ }^{35}$

After entering sensory neurons, the congregate virus expresses latency-associated collinear transcripts (LAT), observed in the trigeminal ganglia of infected mice on the first 24-72 hours, as well as several microRNAs (miRNA). ${ }^{34}$ LAT is the only abundant viral transcript that is expressed in the infected neurons and plays an important role in the silencing of lytic gene expression. ${ }^{34}$ These components deregulate the expression of the host's miRNA, exploiting it to advance its replication or suppressing its genes to facilitate the state of latency and reactivation. ${ }^{36-38}$ Moreover, the existence of certain genetic compounds in some individuals (such as the SNORA31 gene) tends to facilitate the susceptibility to HSV-1's neurovirulence. ${ }^{39}$

This control mechanism is also demonstrated by the study of Bhela and collaborators, when determining susceptibility to viral invasion based on the presence of miR-155 in mice models. Such miRNA confers the risk for developing an inflammatory disease by both promoting the expansion of pro-inflammatory Th1 and Th17 cells as well as amplifying effects on inflammatory gene expression in host macrophages and $\mathrm{T}$ cells. Thereby, when in contact with HSV-1, there is a worsening of the viral pathogenicity, represented by ocular disease, HSE, and zosteriform lesions in the host. Additionally, rapid reactivation effectiveness was observed in ganglionic latent infection with miR-155..$^{40}$ This gene modulation has also been proven in previous studies with rodents. ${ }^{41}$

Latency is also maintained by several CNS immunological factors that suppress viral replication, as represented by IFN- $\beta$ and its genetic modulator $(y 34.5)^{42}$ as well as the APOBEC1 gene $^{43}$ and CD $8+T$ cells. ${ }^{44-46}$ In spite of their apparently benign and harmless character, latent infections not only represent a potential reservoir for viral reactivation, but also that the latent virus itself can contribute to events that modify the pathophysiology of the adjacent disease. ${ }^{12}$ The production of reactivating virions can occur when the host's immune system is compromised, ${ }^{47-50}$ with outcomes varying between local inflammatory and systemic diseases..$^{51-53}$ Transplanted patients who are undergoing immunosuppressant therapy generally present a drastic increase in viral activity ${ }^{54,55}$ and the inflammatory stress of aging also alters immune responses, allowing the reactivation of herpesviruses (HVs). ${ }^{56}$

\section{PATHOPHYSIOLOGY OF HSV-1 ENCEPHALITIS AND NEUROINFLAMMATION INSIGHT}

It is important to ratify that HSV encephalitis is a rare disease, with an incidence of 2-4 cases per 1,000,000 individuals per year, ${ }^{57-59}$ while the trigeminal ganglion reactivation and clinical herpes labialis are common entities. Viral reactivation in the peripheral ganglia corresponds to $70 \%$ of HSE cases, whereas only $30 \%$ of cases correlate to primary HSV infection, whose frequency in children and adolescents is considerable. In both forms of infection, the clinical manifestations and evolution of HSE are the same. ${ }^{60}$

The presence of HSV-1 in the brain results in the continuous activation of the microglia, which contributes to a huge cytokines/chemokines secretion and to a substantial neuroinflammatory activity. Specific pattern-recognition receptors (PRR) on microglia and astrocytes, such as Toll-like receptors (TLR), recognize pathogen-associated molecular patterns (PAMP), such as proteins or nucleic acids from the virus. These PAMP cause an intense type I IFN and antiviral gene expression, which induce the production of numerous pro-inflammatory cytokines, exemplified by the tumor necrosis factor (TNF), interleukin (IL)-1, IFN-alpha, and IL-6. Chemokines produced by microglia (e.g., CCL5, CXCL10, MCP-1, NO) and antimicrobial proteins (e.g., iNOS) are also involved in the modulation of PRR signaling, whose function is to guide apoptosis, cell recruitment, and other inflammatory procedures in the tissue. ${ }^{61}$ The respective TLR are coupled to signaling adaptor systems, resulting in the activation of downstream kinases, consequently modulating intracellular signaling through nuclear factor $\kappa \mathrm{B}(\mathrm{NF}-\mathrm{\kappa B})$ or interferon regulatory factors (IRF). ${ }^{17}$ The currently known TLR on microglia that identify HSV-1 components include TLR2, TLR3, and TLR9. ${ }^{62}$ 
In view of this scenario, the double-edged role of NO during an HSV-1 infection in primary neuronal cultures and in mixed glial cultures has been proven by the study of Cymerys and coworkers, according to which HSV-1 induces a high expression of IFN-alpha, TNF-alpha, CXCL9, and CXCL10 in neuronal cultures. When NO is synthesized, it downregulates the activity of certain cytokines (like IFN-alpha and IFN-beta, from Th1 response). Such cytokines act in viral replication control and in vitro/in vivo spread during primary infection and reactivation, as well as upregulating iNOS in uninfected glial cells. ${ }^{63}$ They also execute important roles in recruiting dendritic cells (DC), natural killer cells (NK), B, and T cells. ${ }^{64}$ In addition, a potent production of type I interferon (IFN) via the cGAS-STING pathway has proven to antagonize HSV-1-driven encephalitis. ${ }^{65,66}$

Hence, disruption of the blood-brain barrier (BBB) succeeds such neuroinflammation enhancement during HSE, leading to unfavorable outcomes like vascular brain edema, hemorrhage, and leukocyte infiltration. ${ }^{67}$ This mechanism is reached due to the high production and binding of cytokines (such as IL-1 $\beta$ and TNF- $\alpha$ ) to ICAM-1 glycoproteins, abundantly expressed on the surface of endothelial cells of the brain vasculature when stimulated by pathogens. ${ }^{68}$ Mitochondrial dysfunction also implicates astrocyte apoptosis through intrinsic and extrinsic pathways, ${ }^{69}$ including alterations in the aquaporin 4 (AQP4) membrane transport protein, intimately involved in water translocation across the BBB, astrogliosis, cell apoptosis, and neuroinflammation. This process leads to an intra/extracellular fluid accumulation, culminating in cytotoxic and vasogenic brain edema. ${ }^{69}$

Piacentini and companions evidenced that HSV-1 also leads to neuronal hyperexcitability as well as altered synaptic activity, which cause dysregulation of intracellular $\mathrm{Ca}^{2+}$ homeostasis and $\beta$ - and $\gamma$-secretases pathways, consequently increasing amyloid precursor protein (APP) processment, amyloid $\beta$ (A $\beta$ ) extracellular plaques, and hyperphosphorylated tau production, found post-mortem in the brains of infected patients as intracellular neurofibrillary tangles. ${ }^{70}$ Markers of primary or reactivated HSV-1 infection, such as anti-HSV-1 IgM antibodies, correlate with the increased risk of $\mathrm{AD}$ in aged individuals, a statement obtained from a large population-based cohort study. ${ }^{71}$ Other studies found an association between IgG anti-NMDAR serostatus and impaired recovery of cognitive performance in individuals with HSE, present in approximately $25 \%$ of patients. ${ }^{72,73}$

Moreover, mitochondrial dysfunction is observed in Alzheimer disease (AD) brains, when associated with a decline in mitochondrial membrane potential in addition to reactive oxygen species (ROS) increasement. ${ }^{74,75}$
These processes are known to influence synaptic communication ${ }^{76,77}$ and rearrangements of mitochondrial DNA. ${ }^{78}$ Therefore, dysregulation of transcription factors, like NF-kB and AP-1, culminates in neuronal apoptosis. Proinflammatory cytokines act on cholinergic neurons and stimulate astrocytes, amplifying proinflammatory signals to induce neurotoxicity. The ATP releasement due to neuronal death subsequently stimulates microglia, an event that maintains such cyclical neuroinflammation. ${ }^{79}$

\section{DEMENTIA AND COGNITIVE DEFICIT PANORAMA: ASSOCIATION WITH HSV-1}

The dementia syndrome is considered as a brain disease that compromises patients' quality of life, family relationships, and productivity of their relatives and caregivers, representing a significant financial and psychosocial burden. ${ }^{80}$ Despite the existence of numerous researches upon dementia and the HSV-1 brain infection individually, the underlying pathophysiological mechanisms of association between both remain uncertain. ${ }^{15}$ As part of the main neuroinflammation supporters and as first line of defense against $\mathrm{CNS}$ infections and damage, the activated state of microglia has been linked to neurotoxicity, neurodegeneration, and chronic neuroinflammation in several disorders including Alzheimer disease, Parkinson disease, amyotrophic lateral sclerosis, and multiple sclerosis. ${ }^{21}$

About this perspective, several studies on the potential risk of HSV-1 infection for neurodegenerative diseases have been conducted. ${ }^{6,7,21,81-86}$ Focusing especially in $\mathrm{AD}$ susceptibility, an increased risk was confirmed for the development of the disease in the presence of the apolipoprotein E epsilon 4 (APOE4) allele, for this allele frequency is much higher between individuals infected by HSV-1 than the non-infected AD population. ${ }^{87}$ Impaired hippocampal neurogenesis was also observed due to $A \beta$ protein production in infected adults, demonstrated by alterations in stem cell proliferation and neuronal differentiation..$^{88}$

HSV-1 encephalitis and Alzheimer disease tend to compromise some common cortical areas that play a key role in behavior, memory, and cognition, such as the orbitofrontal cortex, insular cortex, temporal mesial lobe (especially the hippocampus), and the cingulate gyrus. Damage in those areas are strongly related to the development of neurological and psychiatric sequelae, including seizures, delusions, hallucinations, impairments in working and verbal memory, as well as in executive functions..$^{89,90}$

Therefore, lesions in the orbitofrontal cortex, for example, are deeply related to emotional/social behavior 
changes, such as reversal learning, linked to behavioral disinhibition or even an 'antisocial behavior' and impulsiveness. ${ }^{91}$ The insular cortex enrollment in cognition is related to encoding the interoceptive signals that reflect autonomic activity, especially regarding fear (when interacting with the amygdala) and disgust, even though the last one is still suggestive. ${ }^{92}$ Plenty functional neuroimaging studies have found specific and generic emotional/ behavioral effects related to the insula, which include the anterior cingulate cortex participation in tasks involving perception, intentional action, and consciousness, such as high-level cognitive control, emotional subjective awareness, and empathic and attentional processes. ${ }^{92}$

Regarding magnetic resonance imaging (MRI), interesting results were found in the study by Harris and collaborators, who analyzed the neuropsychological impact of HSV in short-, medium-, and long-terms (4 months; 9-12 months, and >1 year post-discharge from the hospital, respectively). A significant impairment of both anterograde and retrograde memory as well as diminished verbal response were observed in HSV-post-infected patients. Additionally, executive functions, IQ, and naming abilities were also reduced, differing from the group with other causes of encephalitis. This last group had a moderate memory loss with a certain preservation of the executive functions. Such remarkable memory impairment was associated with hippocampal/medial temporal gyrus damage, illustrated on MRI with a substantial volume loss, including the typical hyperintensity presented on the T2-weighted sequence. A proportional correlation between the extent of temporal mesial lobe damage with the severity of anterograde/retrograde amnesia was identified. Moreover, in the short-term, higher rates of depression were noted between the HSV-encephalitis group when compared to the group with other causes of encephalitis. Both depression and anxiety, though, persisted with raised levels in all encephalitis groups in the long-term. ${ }^{93}$

Upon the HSV therapeutic approach, Tzeng and companions conducted a cohort study on HSV-1 and the development of dementia with 8,362 patients $\geq 50$ years of age, post-infection, for a 10-year follow-up, from Taiwan's Longitudinal Health Insurance Database. An exponential chart was formed, which estimates the cumulative risk of dementia in HSV patients over the years. Individuals were stratified into 3 groups, respectively: non-treated HSV infection; treated HSV infection; and non-infected group. Evidently, the sharpest curve was noticed among the individuals of the first group, even though those infected had a 2.56-fold greater risk of developing any type of dementia, including Alzheimer disease, vascular dementia or other dementias. ${ }^{15}$
Through a historical prospective study, Fruchter and collaborators analyzed the impact of HSV on the cognitive capacity of 612 healthy individuals, from a sample of soldiers of the Israeli defense force, whose serum status percentages were $62.2 \% \mathrm{HSV}$-positive and $38.8 \%$ HSV-negative. Cognitive function and linguistic ability of both groups were tested, and HSV seropositive soldiers expressed significantly lower IQ scores when compared to the seronegative ones, thus suggesting the link between HSV-infection and cognitive functional reduction in such individuals..$^{94}$ Similar outcomes were also observed in previous researches with adults with schizophrenia. ${ }^{89,95,96}$

Corroborating the cognitive impacts caused by HSV-1 in healthy persons, Tarter and coworkers evaluated several patients from different age groups that were infected by the virus, including by Cytomegalovirus (CMV), from the Herpesviridae family. Among children (6 to 16 years old), HSV-1 seropositivity was associated with reduced reading and spatial reasoning test scores. Both HSV-1 and CMV seropositivity in middle-aged adults (20 to 59 years old) were associated with impaired cognition speed and, among the aged, with memory impairment. The data indicated that HSV-1 can impair cognition throughout life in all age groups, whose risk of deficit gradually increases the earlier the exposure to the virus takes place in lifetime. ${ }^{14}$

A sum of longitudinal, cross-sectional, transversal, cohort, and experimental studies has been developed upon HSV-1 and its potential risk for dementia and cognitive impairment in infected individuals. Nevertheless, the pathophysiology of the related encephalitis is still not completely understood, as many researches remain mostly suggestive regarding a causal link. A sense of urgency to conduct further studies is required, therefore, to understand the clinical evolution to neurodegeneration and lack of cognition, specifically involving adults, since the majority of available evidence tends to frame the elder population. Through understanding this process and its worldwide panorama, clinicians are able to improve their diagnosis and therapy with the aim of preventing the progression to such devastating outcomes, whenever possible.

\section{ACKNOWLEDGMENTS}

This study was supported by Coordenação de Aperfeiçoamento de Pessoal de Nível Superior (CAPES).

Authors' contributions. EMNC and JCCS Conceptualization; EMNC and JCCS investigation; EMNC and JCCS methodology; EMNC and JCCS writing -original draft; EMNC, LDR and LFO writing-review and editing; LDR and LFO validation; LDR and LFO visualization; JCCS and LFO supervision. 


\section{REFERENCES}

1. Rechenchoski DZ, Faccin-Galhardi LC, Linhares REC, Nozawa C. Herpesvirus: an underestimated virus. Folia Microbiol (Praha). 2017;62(2):151-6. http://doi.org/10.1007/s12223-016-0482-7.

2. Yan C, Luo Z, Li W, Li X, Dallmann R, Kurihara H, et al. Disturbed Yin-Yang balance: stress increases the susceptibility to primary and recurrent infections of herpes simplex virus type 1. Acta Pharm Sin B. 2020;10(3):383-98. http://doi.org/10.1016/j.apsb.2019.06.005

3. Piret J, Boivin G. Immunomodulatory strategies in herpes simplex virus encephalitis. Clin Microbiol Rev. 2020;33(2):e00105-19. http://doi. org/10.1128/CMR.00105-19.

4. Menendez CM, Carr DJJ. Defining nervous system susceptibility during acute and latent herpes simplex virus-1 infection. J Neuroimmunol. 2017;308:43-9. http://doi.org/10.1016/j.jneuroim.2017.02.020

5. Ball MJ. "Limbic predilection in Alzheimer dementia: is reactivated herpesvirus involved?". Can J Neurol Sci. 1982;9(3):303-6. http://doi. org/10.1017/s0317167100044115

6. Harris SA, Harris EA. Herpes simplex virus type 1 and other pathogens are key causative factors in sporadic Alzheimer's disease. J Alzheimers Dis. 2015;48(2):319-53. http://doi.org/10.3233/JAD-142853

7. Eimer WA, Vijaya Kumar DK, Navalpur Shanmugam NK, et al. Alzheimer's disease-associated $\beta$-amyloid is rapidly seeded by herpesviridae to protect against brain infection. Neuron. 2018;99(1):56-63.e3. http://doi. org/10.1016/j.neuron.2018.06.030

8. Jennische E, Eriksson CE, Lange S, Trybala E, Bergström T. The anterior commissure is a pathway for contralateral spread of herpes simplex virus type 1 after olfactory tract infection. J Neurovirol. 2015;21(2):129-47. http://doi.org/10.1007/s13365-014-0312-0

9. Weinstein GM, Small JE. Herpes simplex encephalitis. In: Small JE, Noujaim DL, Ginat DT, Kelly HR, Schaefer PW, editors. Neuroradiology spectrum and evolution of disease. Philadelphia, PA: Elsevier; 2018. p. 50-5.

10. Wang Y, Jia J, Wang Y, Li F, Song X, Qin S, et al. Roles of HSV-1 infection-induced microglial immune responses in CNS diseases: friends or foes?. Crit Rev Microbiol. 2019;45(5-6):581-94. http://doi. org/10.1080/1040841X.2019.1660615

11. Hjalmarsson A, Blomqvist P, Sköldenberg B. Herpes simplex encephalitis in Sweden, 1990-2001: incidence, morbidity, and mortality. Clin Infect Dis. 2007;45(7):875-80. http://doi.org/10.1086/521262

12. Hogestyn JM, Mock DJ, Mayer-Proschel M. Contributions of neurotropic human herpesviruses herpes simplex virus 1 and human herpesvirus 6 to neurodegenerative disease pathology. Neural Regen Res. 2018;13(2):211 21. http://doi.org/10.4103/1673-5374.226380

13. Thomas P, Bhatia T, Gauba D, et al. Exposure to herpes simplex virus, type 1 and reduced cognitive function. J Psychiatr Res. 2013;47(11):1680-5. http://doi.org/10.1016/j.jpsychires.2013.07.010

14. Tarter KD, Simanek AM, Dowd JB, Aiello AE. Persistent viral pathogens and cognitive impairment across the life course in the third national health and nutrition examination survey. J Infect Dis. 2014;209(6):837-44. http:// doi.org/10.1093/infdis/jit616

15. Tzeng NS, Chung CH, Lin FH, et al. Anti-herpetic medications and reduced risk of dementia in patients with herpes simplex virus infections-a nationwide, population-based cohort study in Taiwan. Neurotherapeutics. 2018;15(2):417-29. http://doi.org/10.1007/s13311-018-0611-x

16. Bradshaw MJ, Venkatesan A. Herpes simplex virus-1 encephalitis in adults: pathophysiology, diagnosis, and management. Neurotherapeutics. 2016;13(3):493-508. http://doi.org/10.1007/s13311-016-0433-7

17. Marcocci ME, Napoletani G, Protto V, et al. Herpes simplex virus-1 in the brain: the dark side of a sneaky infection. Trends Microbiol. 2020;28(10):808-20. http://doi.org/10.1016/j.tim.2020.03.003

18. Bearer EL. HSV, axonal transport and Alzheimer's disease: in vitro and in vivo evidence for causal relationships. Future Virol. 2012;7(9):885-99. http://doi.org/10.2217/fvl.12.81

19. Bhatta AK, Keyal U, Liu Y, Gellen E. Vertical transmission of herpes simplex virus: an update. J Dtsch Dermatol Ges. 2018;16(6):685-92. http://doi. org/10.1111/ddg.13529

20. Avila EC, Finger-Jardim F, Gonçalves CV, da Hora VP, Soares MA, Martínez AM. High Incidence of Herpes Simplex Virus-1 in Cord Blood and Placenta Infection of Women in Southern Brazil. Alta incidência do vírus herpes simplex 1 em sangue de cordão e infecção na placenta de mulheres no sul do Brasil. Rev Bras Ginecol Obstet. 2020;42(1):5-11. http://doi. org/10.1055/s-0039-1700794

21. Duarte LF, Farías MA, Álvarez DM, Bueno SM, Riedel CA, González PA. Herpes simplex virus type 1 infection of the central nervous system: insights into proposed interrelationships with neurodegenerative disorders. Front Cell Neurosci. 2019;13:46. http://doi.org/10.3389/ fncel.2019.00046
22. Arduino PG, Porter SR. Herpes Simplex Virus Type 1 infection: overview on relevant clinico-pathological features. J Oral Pathol Med. 2008;37(2):10721. http://doi.org/10.1111/j.1600-0714.2007.00586.x

23. Tzeng NS, Chung CH, Yeh C Bin, Huang RY, Yuh DY, Huang SY, et al. Are chronic periodontitis and gingivitis associated with dementia? A nationwide, retrospective, matched-cohort study in Taiwan. Neuroepidemiology. 2016;47(2):82-93. http://doi.org/10.1159/000449166

24. Suzich JB, Cliffe AR. Strength in diversity: Understanding the pathways to herpes simplex virus reactivation. Virology. 2018;522:81-91. http://doi. org/10.1016/j.virol.2018.07.011

25. Wilson AC, Mohr I. A cultured affair: HSV latency and reactivation in neurons. Trends Microbiol. 2012;20(12):604-11. http://doi.org/10.1016/j. tim.2012.08.005

26. de Almeida SM, Crippa A, Cruz C, de Paola L, de Souza LP, Noronha $L$, et al. Reactivation of herpes simplex virus-1 following epilepsy surgery. Epilepsy Behav Case Rep. 2015;4:76-8. http://doi.org/10.1016/j. ebcr.2014.08.007

27. Steiner I. Herpes simplex virus encephalitis: new infection or reactivation? Curr Opin Neurol. 2011;24(3):268-74. http://doi.org/10.1097/ WCO.0b013e328346be6f

28. Forbes H, Warne B, Doelken L, Brenner N, Waterboer T, Luben R, et al. Risk factors for herpes simplex virus type- 1 infection and reactivation: Cross-sectional studies among EPIC-Norfolk participants. PLoS One. 2019;14(5):e0215553. http://doi.org/10.1371/journal.pone.0215553

29. Looker KJ, Magaret AS, May MT, Turner KM, Vickerman P, Gottlieb SL, et al. Global and regional estimates of prevalent and incident herpes simplex virus type 1 infections in 2012. PLoS One. 2015;10(10):e0140765. http://doi.org/10.1371/journal.pone.0140765

30. Looker KJ, Magaret AS, Turner KM, Vickerman P, Gottlieb SL, Newman LM. Global estimates of prevalent and incident herpes simplex virus type 2 infections in 2012 PLoS One. 2015;10(1):e114989. http://doi. org/10.1371/journal.pone.0114989

31. Zambrano A, Solis L, Salvadores N, Cortés M, Lerchundi R, Otth C. Neuronal cytoskeletal dynamic modification and neurodegeneration induced by infection with herpes simplex virus type 1. J Alzheimers Dis. 2008;14(3):259-69. http://doi.org/10.3233/jad-2008-14301

32. Martin C, Leyton L, Arancibia Y, Cuevas A, Zambrano A, Concha MI, et al. Modulation of the AMPK/Sirt1 axis during neuronal infection by herpes simplex virus type 1. J Alzheimers Dis. 2014;42(1):301-12. http://doi. org/10.3233/JAD-140237

33. Zerr DM, Fann JR, Breiger D, Boeckh M, Adler AL, Xie H, et al. HHV-6 reactivation and its effect on delirium and cognitive functioning in hematopoietic cell transplantation recipients. Blood. 2011;117(19):5243-9. http:// doi.org/10.1182/blood-2010-10-316083

34. Knipe DM, Cliffe A. Chromatin control of herpes simplex virus lytic and latent infection. Nat Rev Microbiol. 2008;6(3):211-21. http://doi. org/10.1038/nrmicro1794

35. Imai T, Arii J, Minowa A, Kakimoto A, Koyanagi N, Kato A, et al. Role of the herpes simplex virus 1 Us3 kinase phosphorylation site and endocytosis motifs in the intracellular transport and neurovirulence of envelope glycoprotein B. J Virol. 2011;85(10):5003-15. http://doi.org/10.1128/JVI.02314-10

36. Pan D, Flores O, Umbach JL, Pesola JM, Bentley P, Rosato PC, et al. A neuron-specific host microRNA targets herpes simplex virus-1 ICPO expression and promotes latency. Cell Host Microbe. 2014;15(4):446-56. http://doi.org/10.1016/j.chom.2014.03.004

37. Held K, Derfuss T. Control of HSV-1 latency in human trigeminal ganglia--current overview. J Neurovirol. 2011;17(6):518-27. http://doi. org/10.1007/s13365-011-0063-0

38. Cokarić Brdovčak M, Zubković A, Jurak I. Herpes Simplex Virus 1 Deregulation of Host MicroRNAs. Noncoding RNA. 2018;4(4):36. http://doi. org/10.3390/ncrna4040036

39. Lafaille FG, Harschnitz O, Lee YS, Zhang P, Hasek ML, Kerner G, et al. Hu man SNORA31 variations impair cortical neuron-intrinsic immunity to HSV1 and underlie herpes simplex encephalitis. Nat Med. 2019;25(12):187384. http://doi.org/10.1038/s41591-019-0672-3

40. Bhela S, Mulik S, Reddy PB, Richardson RL, Gimenez F, Rajasagi NK, et al. Critical role of microRNA-155 in herpes simplex encephalitis. J Immunol. 2014;192(6):2734-43. http://doi.org/10.4049/jimmunol.1302326

41. Umbach JL, Kramer MF, Jurak I, Karnowski HW, Coen DM, Cullen BR. MicroRNAs expressed by herpes simplex virus 1 during latent infection regulate viral mRNAs. Nature. 2008;454(7205):780-3. http://doi. org/10.1038/nature07103

42. Rosato PC, Leib DA. Neuronal interferon signaling is required for protection against herpes simplex virus replication and pathogenesis. PLoS Pathog. 2015;11(7):e1005028. http://doi.org/10.1371/journal.ppat.1005028 
43. Gee P, Ando $\mathrm{Y}$, Kitayama $\mathrm{H}$, Yamamoto SP, Kanemura $\mathrm{Y}$, Ebina $\mathrm{H}$, et al. APOBEC1-mediated editing and attenuation of herpes simplex virus 1 DNA indicate that neurons have an antiviral role during herpes simplex encephalitis. J Virol. 2011;85(19):9726-36. http://doi.org/10.1128/ JVI.05288-11

44. St Leger AJ, Hendricks RL. CD8+T cells patrol HSV-1-infected trigeminal ganglia and prevent viral reactivation. J Neurovirol. 2011;17(6):528-34. http://doi.org/10.1007/s13365-011-0062-1

45. Koyanagi N, Imai T, Shindo K, Sato A, Fujii W, Ichinohe T, et al. Herpes simplex virus- 1 evasion of CD8+ T cell accumulation contributes to viral encephalitis. J Clin Invest. 2017;127(10):3784-95. http://doi.org/10.1172/ JCl92931

46. Menendez CM, Jinkins JK, Carr DJ. Resident T cells are unable to control herpes simplex virus-1 activity in the brain ependymal region during latency. J Immunol. 2016;197(4):1262-75. http://doi.org/10.4049/jimmunol.1600207

47. Walton AH, Muenzer JT, Rasche D, Boomer JS, Sato B, Brownstein BH, et al. Reactivation of multiple viruses in patients with sepsis. PLoS One. 2014;9(2):e98819. http://doi.org/10.1371/journal.pone.0098819

48. Pfender N, Jelcic I, Linnebank M, Schwarz U, Martin R. Reactivation of herpesvirus under fingolimod: A case of severe herpes simplex encephalitis. Neurology. 2015;84(23):2377-8. http://doi.org/10.1212/ WNL.0000000000001659

49. Saito M, Kiyozaki H, Obitsu T, Imoto H, Taniyama Y, Takata O, et al. Herpes simplex virus-1 encephalitis induced by chemoradiotherapy and steroids in an esophageal cancer patient: a case report. BMC Cancer. 2016;16:233. http://doi.org/10.1186/s12885-016-2255-8

50. Mutti C, Curti E, Ciliento R, Melpignano A, Florindo I, Zinno L, et al. Herpes simplex virus 1 encephalitis with normal cerebrospinal fluid after brain radiotherapy in a patient with glioblastoma. A case report and review of literature. Acta Biomed. 2019;90(2):327-30. http://doi.org/10.23750/abm. v90i2.8218

51. Zhang L, Liu JJ, Li MT. Herpes simplex virus type 1 encephalitis and unusual retinitis in a patient with systemic lupus erythematosus. Lupus. 2013;22(13):1403-8. http://doi.org/10.1177/0961203313502112

52. Kobayashi T, Sekar P, Meier J, Streit J. Acute retinal necrosis in a patient with remote severe herpes simplex encephalitis. BMJ Case Rep. 2019;12(5):e229137. http://doi.org/10.1136/bcr-2018-229137

53. Owens GP, Gilden D, Burgoon MP, Yu X, Bennett JL. Viruses and multiple sclerosis. Neuroscientist. 2011;17(6):659-76. http://doi. org/10.1177/1073858411386615

54. Inazawa N, Hori T, Nojima M, Saito M, Igarashi K, Yamamoto M, et al. Virus reactivations after autologous hematopoietic stem cell transplantation detected by multiplex PCR assay. J Med Virol. 2017;89(2):358-62. http:// doi.org/10.1002/jmv.24621

55. Laohathai C, Weber DJ, Hayat G, Thomas FP. Chronic herpes simplex type-1 encephalitis with intractable epilepsy in an immunosuppressed patient. Infection. 2016;44(1):121-5. http://doi.org/10.1007/s15010-0150822-6

56. Bennett JM, Glaser R, Malarkey WB, Beversdorf DQ, Peng J, Kiecolt-Glaser JK. Inflammation and reactivation of latent herpesviruses in older adults. Brain Behav Immun. 2012;26(5):739-76. http://doi.org/10.1016/j. bbi.2011.11.007

57. Rabinstein AA. Herpes virus encephalitis in adults: current knowledge and old myths. Neurol Clin. 2017;35(4):695-705. http://doi.org/10.1016/j. ncl.2017.06.006

58. Jørgensen LK, Dalgaard LS, Østergaard LJ, Nørgaard M, Mogensen TH. Incidence and mortality of herpes simplex encephalitis in Denmark: A nationwide registry-based cohort study. J Infect. 2017;74(1):42-9. http:// doi.org/10.1016/j.jinf.2016.09.004

59. Solomon T, Michael BD, Smith PE, Sanderson F, Davies NW, Hart IJ, et al. Management of suspected viral encephalitis in adults--Association of British Neurologists and British Infection Association National Guidelines. J Infect. 2012;64(4):347-73. http://doi.org/10.1016/j.jinf.2011.11.014

60. Gnann JW Jr, Whitley RJ. Herpes Simplex Encephalitis: an Update. Curr Infect Dis Rep. 2017;19(3):13. http://doi.org/10.1007/s11908-0170568-7

61. Takeuchi $O$, Akira S. Pattern recognition receptors and inflammation. Cell. 2010;140(6):805-20. http://doi.org/10.1016/j.cell.2010.01.022

62. Ma Y, He B. Recognition of herpes simplex viruses: toll-like receptors and beyond. J Mol Biol. 2014;426(6):1133-47. http://doi.org/10.1016/j. jmb.2013.11.012

63. Cymerys J, Kowalczyk A, Mikołajewicz K, Sło囚ska A, Krzy囚owska M Nitric Oxide Influences HSV-1-Induced Neuroinflammation. Oxid Med Cell Longev. 2019;2019:2302835. http://doi.org/10.1155/2019/2302835

64. Conrady CD, Drevets DA, Carr DJ. Herpes simplex type I (HSV-1) infection of the nervous system: is an immune response a good thing?. J Neuroimmunol. 2010;220(1-2):1-9. http://doi.org/10.1016/j.jneuroim.2009.09.013
65. Conrady CD, Zheng M, van Rooijen N, Drevets DA, Royer D, Alleman A, et al. Microglia and a functional type I IFN pathway are required to counter HSV-1-driven brain lateral ventricle enlargement and encephalitis. J Immunol. 2013;190(6):2807-17. http://doi.org/10.4049/jimmunol.1203265

66. Reinert LS, Lopušná K, Winther H, Sun C, Thomsen MK, Nandakumar $R$, et al. Sensing of HSV-1 by the cGAS-STING pathway in microglia orchestrates antiviral defence in the CNS. Nat Commun. 2016;7:13348. http://doi.org/10.1038/ncomms13348

67. Liu H, Qiu K, He Q, Lei Q, Lu W. Mechanisms of Blood-Brain Barrier Disruption in Herpes Simplex Encephalitis. J Neuroimmune Pharmacol. 2019;14(2):157-72. http://doi.org/10.1007/s11481-018-9821-6

68. Lee CW, Wu CH, Chiang YC, Chen YL, Chang KT, Chuang CC, et al. Carbon monoxide releasing molecule-2 attenuates Pseudomonas aeruginosa-induced ROS-dependent ICAM-1 expression in human pulmonary alveolar epithelial cells. Redox Biol. 2018;18:93-103. http://doi. org/10.1016/j.redox.2018.07.001

69. Chu $\mathrm{H}$, Xiang J, Wu P, Su J, Ding H, Tang Y, et al. The role of aquaporin 4 in apoptosis after intracerebral hemorrhage. J Neuroinflammation. 2014;11:184. http://doi.org/10.1186/s12974-014-0184-5

70. Piacentini R, Civitelli L, Ripoli C, Marcocci ME, De Chiara G, Garaci E, et al. HSV-1 promotes Ca2+ -mediated APP phosphorylation and A $\beta$ accumulation in rat cortical neurons. Neurobiol Aging. 2011;32(12):2323.e13-2323. e2.323E26. http://doi.org/10.1016/j.neurobiolaging.2010.06.009

71. Letenneur L, Pérès K, Fleury H, Garrigue I, Barberger-Gateau P, Helmer $\mathrm{C}$, et al. Seropositivity to herpes simplex virus antibodies and risk of Alzheimer's disease: a population-based cohort study. PLoS One. 2008;3(11):e3637. http://doi.org/10.1371/journal.pone.0003637

72. Westman G, Sohrabian A, Aurelius E, Ahlm C, Schliamser S, Sund F, et al. Clinical significance of lgM and IgA class anti-NMDAR antibodies in herpes simplex encephalitis. J Clin Virol. 2018;103:75-80. http://doi. org/10.1016/j.jcv.2018.04.007

73. Westman G, Studahl M, Ahlm C, Eriksson BM, Persson B, Rönnelid $J$, et al. N-methyl-d-aspartate receptor autoimmunity affects cognitive performance in herpes simplex encephalitis. Clin Microbiol Infect. 2016;22(11):934-40. http://doi.org/10.1016/j.cmi.2016.07.028

74. Oka S, Leon J, Sakumi K, Ide T, Kang D, LaFerla FM, et al. Human mitochondrial transcriptional factor A breaks the mitochondria-mediated vicious cycle in Alzheimer's disease. Sci Rep. 2016;6:37889. http://doi. org/10.1038/srep37889

75. Rönnbäck A, Pavlov PF, Mansory M, Gonze P, Marlière N, Winblad B, et al. Mitochondrial dysfunction in a transgenic mouse model expressing human amyloid precursor protein (APP) with the Arctic mutation. J Neurochem. 2016;136(3):497-502. http://doi.org/10.1111/jnc.13410

76. Pérez MJ, Vergara-Pulgar K, Jara C, Cabezas-Opazo F, Quintanilla RA. Caspase-Cleaved Tau Impairs Mitochondrial Dynamics in Alzheimer's Disease. Mol Neurobiol. 2018;55(2):1004-18. http://doi.org/10.1007/ s12035-017-0385-X

77. Cabezas-Opazo FA, Vergara-Pulgar K, Pérez MJ, Jara C, Osorio-Fuentealba C, Quintanilla RA. Mitochondrial dysfunction contributes to the pathogenesis of alzheimer's disease. Oxid Med Cell Longev. 2015;2015:509654. http://doi.org/10.1155/2015/509654

78. Chen Y, Liu C, Parker WD, Chen H, Beach TG, Liu X, et al. Mitochondrial DNA rearrangement spectrum in brain tissue of alzheimer's disease: analysis of 13 cases. PLoS One. 2016;11(6):e0154582. http://doi.org/10.1371/ journal.pone.0154582

79. Glass CK, Saijo K, Winner B, Marchetto MC, Gage FH. Mechanisms underlying inflammation in neurodegeneration. Cell. 2010;140(6):918-34. http://doi.org/10.1016/j.cell.2010.02.016

80. Ferretti C, Sarti FM, Nitrini R, Ferreira FF, Brucki SMD. An assessment of direct and indirect costs of dementia in Brazil. PLoS One. 2018;13(3):e0193209. http://doi.org/10.1371/journal.pone.0193209

81. Mancuso R, Baglio F, Cabinio M, et al. Titers of herpes simplex virus type 1 antibodies positively correlate with grey matter volumes in Alzheimer's disease. J Alzheimers Dis. 2014;38(4):741-5. http://doi.org/10.3233/ JAD-130977

82. Lövheim H, Gilthorpe J, Adolfsson R, Nilsson LG, Elgh F. Reactivated herpes simplex infection increases the risk of Alzheimer's disease. Alzheimers Dement. 2015;11(6):593-9. http://doi.org/10.1016/j.jalz.2014.04.522

83. Kobayashi N, Nagata T, Shinagawa S, et al. Increase in the IgG avidity index due to herpes simplex virus type 1 reactivation and its relationship with cognitive function in amnestic mild cognitive impairment and Alzheimer's disease. Biochem Biophys Res Commun. 2013;430(3):907-11. http://doi.org/10.1016/j.bbrc.2012.12.054

84. Itzhaki RF. Herpes simplex virus type 1 and Alzheimer's disease: increasing evidence for a major role of the virus. Front Aging Neurosci. 2014;6:202. http://doi.org/10.3389/fnagi.2014.00202

85. Itzhaki RF. Herpes and Alzheimer's Disease: Subversion in the Central Nervous System and How It Might Be Halted. J Alzheimers Dis. 2016;54(4):1273-81. http://doi.org/10.3233/JAD-160607 
86. De Chiara G, Piacentini R, Fabiani M, Mastrodonato A, Marcocci ME, Limongi $D$, et al. Recurrent herpes simplex virus- 1 infection induces hallmarks of neurodegeneration and cognitive deficits in mice. PLoS Pathog. 2019;15(3):e1007617. http://doi.org/10.1371/journal.ppat.1007617

87. McManus RM, Heneka MT. Role of neuroinflammation in neurodegeneration: new insights. Alzheimers Res Ther. 2017;9(1):14. http://doi. org/10.1186/s13195-017-0241-2

88. Li Puma DD, Piacentini R, Leone L, Gironi K, Marcocci ME, De Chiara $\mathrm{G}$, et al. Herpes Simplex Virus Type-1 Infection Impairs Adult Hippocampal Neurogenesis via Amyloid- $\beta$ Protein Accumulation. Stem Cells. 2019;37(11):1467-80. http://doi.org/10.1002/stem.3072

89. Prasad KM, Watson AM, Dickerson FB, Yolken RH, Nimgaonkar VL. Exposure to herpes simplex virus type 1 and cognitive impairments in individuals with schizophrenia. Schizophr Bull. 2012;38(6):1137-48. http:// doi.org/10.1093/schbul/sbs046

90. Chandra A, Valkimadi PE, Pagano G, Cousins O, Dervenoulas G, Politis $\mathrm{M}$, et al. Applications of amyloid, tau, and neuroinflammation PET imaging to Alzheimer's disease and mild cognitive impairment. Hum Brain Mapp. 2019;40(18):5424-42. http://doi.org/10.1002/hbm.24782

91. Jonker FA, Jonker C, Scheltens P, Scherder EJ. The role of the orbitofrontal cortex in cognition and behavior. Rev Neurosci. 2015;26(1):1-11. http:// doi.org/10.1515/revneuro-2014-0043
92. Gasquoine PG. Contributions of the insula to cognition and emotion. Neuropsychol Rev. 2014;24(2):77-87. http://doi.org/10.1007/s11065-0149246-9

93. Harris L, Griem J, Gummery A, Marsh L, Defres S, Bhojak M, et al. Neuropsychological and psychiatric outcomes in encephalitis: A multi-centre case-control study. PLoS One. 2020;15(3):e0230436. http://doi. org/10.1371/journal.pone.0230436

94. Fruchter E, Goldberg S, Fenchel D, Grotto I, Ginat K, Weiser M. The impact of Herpes simplex virus type 1 on cognitive impairments in young, healthy individuals - A historical prospective study. Schizophr Res. 2015;168(12):292-6. http://doi.org/10.1016/j.schres.2015.08.036

95. Prasad KM, Eack SM, Goradia D, Pancholi KM, Keshavan MS, Yolken RH, et al. Progressive gray matter loss and changes in cognitive functioning associated with exposure to herpes simplex virus 1 in schizophrenia: a longitudinal study. Am J Psychiatry. 2011;168(8):822-30. http://doi. org/10.1176/appi.ajp.2011.10101423

96. Yolken RH, Torrey EF, Lieberman JA, Yang S, Dickerson FB. Serological evidence of exposure to Herpes Simplex Virus type 1 is associated with cognitive deficits in the CATIE schizophrenia sample. Schizophr Res. 2011;128(1-3):61-5. http://doi.org/10.1016/j.schres.2011.01.020 